\title{
Jurist-Diction
}

Volume 4 No. 1, Januari 2021

\section{Restriksi Perdagangan Internasional Atas Dasar National Security yang Dilakukan oleh Jepang terhadap Korea Selatan}

\author{
Jesika Althea Widhia Nugraha \\ jesika.althea@gmail.com \\ Universitas Airlangga
}

How to cite:

Jesika Althea Widhia Nugraha,

'Restriksi Perdagangan

Internasional Atas Dasar

National Security yang

Dilakukan oleh Jepang

terhadap Korea Selatan' (2021)

Vol. 4 No. 1 Jurist-Diction.

Histori artikel:

Submit 11 November 2020;

Diterima 10 Desember 2020;

Diterbitkan 5 Januari 2021.

DOI:

10.20473/jd.v4i1.24297

p-ISSN: 2721-8392

e-ISSN: $2655-8297$

\section{Abstract}

National Security is one of the exceptional clause which can be used by a country to deviate from the provisions of GATT 1994. As a member of the WTO, this exceptional clause becomes the basis of the trade restrictions imposed by Japan on South Korea. This study aims to determine the scope and application of national security exceptions in GATT 1994 and to conduct an analysis of the measure taken by Japan to South Korea. National security in the WTO is related to the classic function of a state, namely maintaining internal law and public order as well as protecting the physical interests of the region and its inhabitants. In using the national security exception, the classic function of a state must be objectively proven to be threatened by one of the subparagraphs of Article XXI (b) GATT 1994. In implementing trade restrictions on South Korea, Japan have to prove objectively that the classic functions of its country were threatened according to Article XXI (b) of the 1994 GATT.

Keywords: National Security; Trade Restriction.

\section{Abstrak}

National Security merupakan salah satu alasan yang dapat digunakan oleh negara untuk menyimpangi ketentuan-ketentuan dalam GATT 1994. Sebagai negara anggota WTO, alasan tersebut menjadi dasar bagi Jepang untuk memberlakukan restriksi perdagangan terhadap Korea Selatan. Penelitian ini bertujuan untuk mengetahui ruang lingkup dan penerapan dari national security exception dalam GATT 1994 serta melakukan analisis terhadap tindakan yang dilakukan oleh Jepang kepada Korea Selatan. National security yang dimaksud dalam WTO adalah terkait fungsi klasik negara yaitu memelihara hukum internal dan ketertiban umum negara serta melindungi kepengtingan fisik wilayah dan penduduknya. Dalam menggunakan national security exception, fungsi klasik negara harus terancam oleh salah satu dari subparagraf Pasal XXI(b) GATT 1994 yang harus secara objektif terbukti. Dalam menerapkan restriksi perdagangan terhadap Korea Selatan, Jepang harus terlebih dahulu membuktikan secara objektif sesuai Pasal XXI(b) GATT 1994 bahwa fungsi klasik negaranya terancam

Kata Kunci: Keamanan Nasional; Restriksi Perdagangan.

Copyright (C) 2021 Universitas Airlangga 


\section{Pendahuluan}

WTO merupakan organisasi yang berurusan langsung dengan regulasi terkait perdagangan antarnegara. Peraturan-peraturan yang terdapat pada WTO merupakan perjanjian-perjanjian hasil negosiasi yang dilakukan oleh negara-negara anggota WTO. Salah satu perjanjian tersebut ialah perbaikan dari General Agreement on Tariffs and Trade 1947 (GATT 1947). Perjanjian yang direvisi menjadi General Agreement on Tariffs and Trade 1994 (GATT 1994) tersebut merupakan perjanjian internasional yang berisi ketentuan-ketentuan serta prinsip-prinsip guna mengurangi hambatan-hambatan dalam perdagangan internasional. Pada dasarnya, negaranegara anggota WTO dilarang menerapkan kebijakan yang melanggar ketentuanketentuan GATT 1994 atau dalam kata lain menerapkan tindakan yang diskriminatif untuk menghambat perdagangan internasional. ${ }^{1}$ Namun, GATT 1994 memberikan beberapa alasan pengecuali yang dapat digunakan oleh negara-negara anggota WTO agar dapat menyimpangi ketentuan yang terdapat didalamnya.

Diaturnya alasan-alasan pengecualian tersebut dimaksudkan agar negara anggota WTO dapat menerapkan kebijakan yang tidak sesuai dengan ketentuan pada WTO Agreement untuk melindungi hal-hal yang dianggap penting oleh negara anggota WTO. ${ }^{2}$ Salah satunya adalah alasan keamanan yang diatur pada Pasal XXI GATT 1994. Alasan pengecualian ini setidaknya menjadi dasar dari dua sengketa yang diajukan ke Dispute Settlement Body dalam WTO. Salah satu sengketa tersebut terjadi antara Jepang dan Republik Korea yang selanjutnya disebut sebagai Korea Selatan.

Pada bulan Juli 2019, Jepang melakukan restriksi terhadap tiga bahan kimia yang diekspor ke Korea Selatan yaitu fluorinated polyimide, photoresist dan hydrogen fluoride. ${ }^{3}$ Bahan-bahan kimia tersebut merupakan bahan dasar

${ }^{1}$ Peter van den Bossche,[et.,al.], Pengantar Hukum WTO (World Trade Organization) (Yayasan Obor Indonesia 2010).[8].

${ }^{2}$ Glyn Ayres, [et.,al.], "General and Security Exceptions Under the GATT 1994 and the GATS”, dalam Shawkat Alam, [et.,al.], (eds), International Trade Law and The WTO (The Federation Press 2013).[226].

${ }^{3}$ Catherine Kim, 'The Escalating Trade War Between South Korea and Japan, Explained' (Vox, 2019) <www.vox.com/world/2019/8/9/20758025/trade-war-south-korea-japan> accessed 25 Agustus 2019. 
yang penting untuk membuat semikonduktor. ${ }^{4} \mathrm{Hal}$ ini tentunya akan berdampak terhadap perusahaan-perusahaan elektronik yang terdapat di Korea Selatan seperti LG Display Co., Samsung Electronics, dan SK Hynix Inc. ${ }^{5}$ Restriksi bahan-bahan kimia yang diterapkan Jepang kepada Korea Selatan tersebut dilakukan dengan cara mewajibkan perusahaan-perusahan Jepang untuk mengajukan lisensi ekspor apabila hendak melakukan ekspor bahan-bahan kimia ke Korea Selatan. Proses pengajuan lisensi ini dapat menghabiskan waktu selama 90 hari. ${ }^{6}$ Restriksi yang dilakukan oleh Pemerintah Jepang ini diterapkan atas dasar alasan national security. ${ }^{7}$ Jepang menuding bahwa Korea Selatan telah membocorkan informasi sensitif serta mengirimkan sejumlah bahan kimia guna peralatan militer kepada Korea Utara. ${ }^{8}$ Sedangkan Korea Selatan berpendapat bahwa kebijakan lisensi yang diterapkan Jepang ini merupakan sebuah pelanggaran hukum dan pada dasarnya berlandaskan alasan politis. ${ }^{9}$ Perkara ini berkaitan dengan pembahasan mengenai ketentuan WTO dalam menetapkan bahwa suatu hal dianggap sebagai ancaman bagi keamanan sehingga sebuah negara diizinkan untuk melakukan restriksi perdagangan berdasarkan Pasal XXI GATT 1994. Menyadari pentingnya definisi dan limitasi terhadap restriksi perdagangan maka penelitian ini disusun untuk memberikan kajian lebih dalam terhadap ketentuan WTO terkait isu hukum ini.

\footnotetext{
${ }^{4}$ Pengertian semikonduktor adalah: 'suatu bahan yang mempunyai sifat hantaran listrik diantara isolator dan konduktor.' Lihat: 'Semikonduktor' <www.definisimenurutparaahli.com/ pengertian-semikonduktor-dan-contohnya> accessed 26 Agustus 2019.

5 Robert Farley, 'Japanese Tech Export Controls on South Korea?' (The Diplomat, 2019) $<$ www.thediplomat.com/2019/07/japanese-tech-export-controls-on-south-korea/> accessed 24 Agustus 2019.

${ }^{6}$ Ben Dooley, [et.,al.], 'Japan Imposes Broad New Trade Restrictions on South Korea' (New York Times, 2019) <www.nytimes.com/2019/08/01/business/japan-south-korea-trade.html> accessed 24 Agustus 2019.

7 Celeste L. Arrington, 'Japan claims it's restricting exports to South Korea because of 'national security'. Here is the real reason why' (Washington Post, 2019) <https://www. washingtonpost.com/politics/2019/07/18/japan-claims-its-restricting-exports-south-korea-becausenational-security-heres-real-reason-why/> accessed 8 Desember 2019.

${ }^{8}$ Catherin Kim, Loc. Cit.

9 Satoshi Sugiyama, 'Japan, 'Surprised' by South Korean Response to Export Control, Accuses Seoul of Trying to Make The Issue About Free Trade' (The Japan Times, 2019) <https:// www.japantimes.co.jp/news/2019/07/10/business/japan-surprised-south-korean-response-exportcontrol-accuses-seoul-trying-make-issue-free-trade/> accessed 24 Agustus 2019.
} 
Penelitian ini menggunakan tipe penelitian yuridis normatif, yaitu penelitan hukum dengan cara melakukan penelitian secara sistematis terhadap bahan hukum primer dan bahan hukum sekunder. Sesuai dengan tipe penelitian yang telah dipaparkan di atas, maka penelitian ini akan menelaah kaidah perjanjian internasional dan putusan hakim tentang restriksi perdagangan internasional atas dasar national security serta literatur yang berkaitan dengan isu hukum yang dibahas.

\section{National Security dalam World Trade Organization General Agreement on Tariff and Trade 1994}

Salah satu pengaturan terkait national security dalam WTO terdapat dalam Pasal XXI GATT 1994. Pada dasarnya Pasal XXI GATT 1994 tersebut merupakan pengecualian terkait keamanan (security exception). Berikut adalah isi dari pasal tersebut:

\section{Article XXI: Security Exceptions}

Nothing in this Agreement shall be construed:

(a) to require any contracting party to furnish any information the disclosure of which it considers contrary to its essential security interests; or

(b) to prevent any contracting party from taking any action which it considers necessary for the protection of its essential security interests

(i) relating to fissionable materials or the materials from which they are derived;

(ii)relating to the traffic in arms, ammunition and implements of war and to such traffic in other goods and materials as is carried on directly or indirectly for the purpose of supplying a military establishment; taken in time of war or other emergency in international relations; or

(c) to prevent any contracting party from taking any action in pursuance of its obligations under the United Nations Charter for the maintenance of international peace and security. ${ }^{10}$

Keamanan yang dimaksud pada pasal tersebut dibagi menjadi 2 yaitu national security dan international security. Pengaturan terkait national security tertulis pada huruf (a) dan (b) Pasal XXI GATT 1994. Serangkaian kata 'its essential security

${ }^{10}$ Pasal XXI General Agreement on Tariff and Trade 1994. 
interest' merupakan national security interest dari negara anggota WTO. ${ }^{11}$ Dalam kedua huruf (a) dan (b) pada Pasal XXI GATT 1994 tersebut terdapat rangkaian kata: “... its essential security interest.” Kata 'its' secara gramatik merupakan kata kepunyaan negara anggota WTO. Sedangkan 'essential security interest' tidak memiliki definisi yang baku. Namun bila diartikan secara gramatikal maka “... its essential security interest." memiliki arti sebagai kepentingan keamanan dari negara anggota WTO. Dari apa yang tercantum pada Analytical Index Article XXI GATT dapat dimengerti bahwa masing-masing negara memiliki kewenangannya sendiri untuk memutuskan hal yang dianggap sebagai 'essential security interest' secara unilateral. ${ }^{12}$

Pada tahun 1986 terdapat sebuah Panel Report terkait kasus yang terjadi antara Amerika Serikat dengan Nikaragua. Presiden Amerika Serikat, pada bulan Mei 1985 melarang segala perdagangan serta transaksi yang berkaitan dengan transportasi udara dan laut dengan Nikaragua. ${ }^{13}$ Presiden Ronald Reagan menyatakan bahwa tindakan-tindakan dari Pemerintah Nikaragua mengancam national security interest dari Amerika Serikat. ${ }^{14}$ Nikaragua berpendapat bahwa embargo yang dilakukan tidak sesuai dengan Pasal XXI GATT 1994 sebab negara kecil yang sedang berkembang seperti Nikaragua tidak mungkin menyebabkan ancaman terhadap negara besar yang maju seperti Amerika Serikat. ${ }^{15}$ Namun representatif Amerika Serikat berpendapat bahwa berdasarkan klausula Pasal XXI GATT 1994, ancaman terhadap 'essential security interest' merupakan kewenangan mutlak dari negara

${ }^{11}$ SR.19/12. Pada pertemuan di Jenewa tahun 1961, tercatat sebuah pembahasan terkait pemboikotan yang dilakukan oleh Ghana terhadap barang-barang yang berasal dari Portugal. Ghana berpendapat bahwa tindakannya sesuai dengan Pasal XXI GATT. Dari pernyataan yang dikeluarkan oleh Ghana, dapat disimpulkan bahwa menurut Ghana arti dari its essential security interest sama dengan security interest dari sebuah negara (national security).

C/M/159.[14]. Pada sebuah rapat pada tahun 1982, Argentina mengeluarkan pendapat terkait penerapan Pasal XXI GATT. Argentina menilai bahwa Pasal XXI GATT merupakan sebuah ketentuan yang restriktif. Oleh karena itu seyogyanya untuk menjustifikasi penerapan Pasal XXI GATT, negara yang menerapkannya harus menyatakan alasan national security-nya. Dapat dilihat bahwa Argentina menyamakan essential security interest dengan national security interest.

${ }^{12}$ Analytical Index Article XXI.[600-601].

${ }^{13}$ Panel Report, United States - Trade Measures Affecting Nicaragua (L/6053).

${ }^{14}$ ibid.

15 ibid. 
terkait untuk menentukan. Panel menyatakan demikian: ${ }^{16}$

"... the Panel could not examine or judge the validity of or the motivation for the invocation of Article XXI(b)(iii) by the United States. The Panel concluded that, as it was not authorized to examine the justification for the United States' invocation of a general exception to the obligations under the General Agreement, it could find the United States neither to be complying with its obligations under the General Agreement nor to be failing to carry out its obligations under that Agreement."

Singkatnya, dalam bagian kesimpulan Panel menyatakan bahwa Panel tidak memiliki kewenangan untuk menilai keabsahan dari hal-hal yang dialkukan oleh Amerika Serikat atas dasar Pasal XXI GATT 1994. ${ }^{17}$ Sehingga dari kasus ini dapat disimpulkan bahwa WTO membenarkan bahwa suatu negara memang memiliki kewenangan untuk secara sepihak menentukan apa yang dimaksud dengan 'essential security interest' atau national security interest.

\section{a. Pasal XXI (a) GATT 1994}

Huruf (a) Pasal XXI GATT 1994 memberikan izin kepada negara anggota WTO untuk tidak memberikan informasi tertentu terhadap hal-hal yang dianggapnya bertentangan dengan national security interest. Menurut Tshwane Principles, berbagai pihak memiliki hak akses atas informasi ${ }^{18}$ Tshwane Principles juga mengakui bahwa hak tersebut boleh disimpangi dengan alasan national security. Dapat dilihat bahwa informasi merupakan salah satu komponen dari kepentingan nasional sehingga hal tersebut dapat menjadi alasan bagi suatu negara untuk menyimpangi ketentuan dalam GATT 1994. ${ }^{19}$ Namun demi kepastian hukum, menurut prinisip ke-2 dari Tshwane Principle ketika sebuah negara ingin melimitasi hak akses atas informasi atas dasar national security

\footnotetext{
${ }^{16}$ ibid, para. 5.3 .

${ }^{17} \mathrm{ibid}$, paras. 5.2-5.3.

${ }^{18}$ Tshwane Principles adalah nama sebutan dari Global Principles on National Security and The Right to Information yang merupakan prinsip-prinsip yang dirancang oleh 22 organisasi internasional dan pusat akademik dengan berkonsultasi dengan sekitar 500 ahli dari 70 negara dalam 14 pertemuan yang diadakan di seluruh dunia yang difasilitasi oleh Open Society Justice Inisative. Lihat: $<$ http://www.opensocietyfoundations.org/publications/global-principlesnational-securityand-freedom-information-tshwane-principles> accessed 26 Agustus 2019

${ }^{19}$ Prabhakaran Paleri, National Security: Imperatives and Challenges (Tata McGraw-Hill
} 2008).[71]. 
interest, negara tersebut harus memberikan definisi tetap national security dalam hukum nasionalnya. ${ }^{20}$

\section{b. Pasal XXI (b) GATT 1994}

Selanjutnya huruf (b) mencegah negara anggota dari melakukan suatu tindakan guna melindungi national security interest-nya. Tindakan yang dimaksud ditujukan terkait bahan-bahan fisi; lalu lintas senjata, amunisi, peralatan perang dan bahan lainnya yang secara langsung atau tidak langsung digunakan untuk keperluan memasok kebutuhan militer; dan dilakukan saat perang atau keadaan genting dalam hubungan internasional. Dapat dilihat bahwa dalam huruf (b) national security interest yang dimaksud adalah terkait kepentingan fisik dari suatu negara.

Memang dapat dianalisis dari penjelasan di atas bahwa security yang dimaksud dalam Pasal XXI(b) GATT 1994 berfokus pada military security. Namun tidak terdapat interpretasi maupun ruang lingkup yang jelas dari apa yang dianggap sebagai 'essential security interest' oleh WTO. Setiap negara memiliki kebebasan untuk menentukannya sendiri. Namun akhir-akhir ini konsep bahwa Pasal XXI GATT 1994 hanya dapat ditentukan oleh negara yang bersangkutan dan tidak ada pihak yang dapat melakukan peninjauan terhadapnya mulai berubah. Hal tersebut disebabkan atas munculnya Panel Report pada tahun 2019 yaitu terkait Russia Measures Concerning Traffic in Transit (WT/DS512/R).

Panel Report ini diterbitkan sebagai hasil dari upaya penyelesaian sengketa yang terjadi antara Ukraina dan Rusia. Sengketa tersebut disebabkan oleh restriksi yang diterapkan oleh Rusia terhadap arus lalu lintas transit barang yang berasal dari Ukraina. Rusia berargumen bahwa kebijakan tersebut diterapkan atas dasar Pasal XXI(b)(iii) GATT 1994. ${ }^{21}$ Rusia menambahkan bahwa menurut pasal tersebut negaranya memiliki kewenangan untuk melakukan tindakan-tindakan yang dianggap penting untuk national security interest-nya ketika terjadi kegentingan dalam hubungan internasional. ${ }^{22}$ Selanjutnya seperti sebagaimana tertulis dalam

\footnotetext{
${ }^{20}$ Principle 2 Global Principles on National Security and The Right to Information.

${ }^{21} \mathrm{WT} / \mathrm{DS} 512 / \mathrm{R} / \mathrm{Add} .1$, Annex C-3, paras. 34-35.

${ }^{22}$ ibid, paras, 35-36.
} 
Analytical Index Article XXI, Rusia juga berpendapat bahwa penilaian terhadap national security interest merupakan diskresi yang hanya dimiliki oleh negara terkait, serta bahwa national security negara yang satu dengan negara yang lainnya berbeda. ${ }^{23}$ Ukraina pun berpendapat bahwa setiap negara dapat menentukan ruang lingkup national security interest-nya namun dalam penerapan klausula Pasal XXI GATT 1994, sebuah negara tidak memiliki diskresi secara total dan tidak dapat menentukan national security interest secara unilateral. ${ }^{24}$ Ukraina juga berargumen bahwa Panel juga memiliki kewenangan untuk secara objektif memberikan arti akan apa yang dimaksud dengan 'emergency in international relations' dan 'essential security interest' ${ }^{25}$

Berdasarkan pendapat Panel, untuk menentukan apakah Panel memiliki jurisdiksi untuk menentukan keabsahan penerapan Pasal XXI(b)(iii) GATT 1994 yang dilakukan oleh Rusia, maka diperlukan analisis terhadap pasal tersebut terlebih dahulu. ${ }^{26}$ Analisis terhadap chapeau dan ayat (iii) dari pasal tersebut dimaksudkan untuk menemukan apakah terhadap pasal tersebut dapat dilakukan interpretasi secara objektif. Apabila dapat, maka Panel berwenang untuk melakukan peninjauan atasnya. Dengan analisis yang dilakukan, Panel pun akhirnya menemukan bahwa ayat (iii) dari pasal tersebut dapat dilakukan interpretasi secara objektif.

Selanjutnya pada sengketa antara Rusia dan Ukraina, Panel menyatakan bahwa 'essential security interest'yang tertulis pada chapeau Pasal XXI(b) GATT 1994 memiliki ruang lingkup yang lebih kecil dibandingkan security interest yang lebih umum. Panel menyatakan bahwa yang dimaksud dengan 'essential security interest' adalah hal-hal yang terkait dengan fungsi-fungsi klasik negara. ${ }^{27} \mathrm{Hal}-$ hal yang dimaksud adalah baik secara internal dan eksternal. 'Essential security interest' secara internal terkait pemeliharaan hukum dan ketertiban umum, sedangkan secara eksternal terkait perlindungan dari ancaman terhadap wilayah dan

\footnotetext{
${ }^{23}$ ibid, paras. 46-47.

${ }^{24}$ ibid, Annex C-1, paras. 48.

${ }^{25}$ ibid. paras. $47,49-50$.

${ }^{26} \mathrm{WT} / \mathrm{DS} 512 / \mathrm{R}$, para. 7.58 .

${ }^{27} \mathrm{ibid}$, para. 7.130 .
} 
penduduk. Sekalipun Panel memberikan ruang lingkup tersebut, Panel kemudian menyatakan bahwa negara memiliki diskresi dalam menentukan apa yang dimaksud sebagai 'essential security interest'-nya dan bilamana suatu tindakan dianggap penting untuk dilakukan guna mengahadapi ancaman terhadap 'essential security interest ${ }^{28}$ Sehingga Panel tidak dapat melakukan interpretasi secara objektif terkait hal tersebut. Namun Panel juga menambahkan bahwa interpretasi yang dilakukan negara atas 'essential security interest' harus dilakukan atas dasar itikad baik. ${ }^{29}$ Itikad baik dapat ditunjukan oleh negara yang menerapkan Pasal XXI GATT 1994 dengan memberikan hal-hal atau peristiwa konkrit apa saja yang dimaksud sebagai ancaman terhadap national security interest-nya.

Dengan analisis yang dilakukan oleh Panel pada kasus Rusia-Ukraina, Panel memberikan kesimpulan bahwa Panel memiliki kewenangan untuk menilai keabsahan dari penerapan Pasal XXI GATT 1994. Sekalipun negara memiliki diskresi untuk menentukan sendiri apa yang dimaksud dengan 'essential security interest'negaranya, dalam penerapannya hal tersebut harus dilakukan dengan itikad baik. Serta untuk menggunakan Pasal XXI(b), national security yang dimaksud oleh negara harus secara objektif memenuhi salah satu subparagraf yang ada pada Pasal XXI(b) GATT 1994. Dengan ini, Panel melakukan penilaian atas penerapan restriksi yang dilakukan oleh Rusia atas dasar national security dan menemukan bahwa kondisi, peristiwa, dan fakta yang ada menyebabkan Rusia dapat dikatakan telah menerapkan Pasal XXI(b) (iii) GATT secara tepat dan sah. Panel Report ini merupakan putusan Panel WTO pertama yang menyatakan bahwa panel memiliki kewenangan untuk menilai national security sebagai alasan dilakukannya restriksi perdagangan.

Berdasarkan putusan di atas didapati bahwa sebuah negara tidak memiliki diskresi yang utuh dalam menentukan national security dalam Pasal XXI(b) GATT 1994. Dapat dilakukan penilaian secara objektif terhadap subparagraf dari Pasal

\footnotetext{
${ }^{28}$ ibid, para. 7.131 .

${ }^{29}$ ibid. para 7.132 .

Hal ini sesuai dengan Pasal 26 Vienna Convention on the Law of Treaties 1969 yang mengatur bahwa sebuah perjanjian internasional harus dilaksanakan berdasarkan itikad baik.
} 
XXI(b) GATT 1994. Berikut adalah beberapa penjelasan terkait objektivitas ayat (i), (ii), (iii) Pasal XXI(b) GATT 1994.

(i) relating to fissionable materials or the materials from which they are derived Ayat ini cukup mudah untuk dinilai secara objektif. Ayat (i) dari huruf b mengatur terkait kepentingan nasional secara fisik yang dapat terancam oleh bahan-bahan fisi. Contoh bahan fisi adalah uranium yang digunakan pada senjata nuklir untuk mengebom Hiroshima dan plutonium yang digunakan untuk mengebom Nagasaki. ${ }^{30}$ Sebuah negara dapat menggunakan Pasal XXI(b) (i) GATT 1994 sebagai dasar menyimpangi aturan GATT ketika terdapat ancaman atau gangguan yang melibatkan bahan fisi.

(ii) relating to the traffic in arms, ammunition and implements of war and to such traffic in other goods and materials as is carried on directly or indirectly for the purpose of supplying a military establishment;

Ayat (ii) dari huruf b secara umum mengatur terkait lalu lintas barang yang berkaitan dengan perang dan militer. Barang yang dimaksud diantaranya adalah barang-barang yang dapat digunakan untuk kepentingan militer dan barangbarang yang berpotensi menyebabkan perang. ${ }^{31}$ Selain itu, bahan mentah atau barang-barang yang terbukti diperdagangkan dengan tujuan untuk memasok keperluan militer juga termasuk dalam ayat ini. ${ }^{32}$ Bahan mentah seperti bijih besi yang belum diolah pun termasuk dalam ketentuan Pasal XXI(b)(ii) GATT 1994 ketika bijih besi tersebut dipasok ke instansi militer. ${ }^{33}$ Ketika negara menilai bahwa national security-nya terancam akibat lalu lintas perdagangan senjata atau barang lainnya yang berkaitan dengan militer atau perang, maka negara dapat menyimpangi ketentuan GATT 1994 atas dasar Pasal XXI(b)(ii) GATT 1994.

\footnotetext{
${ }^{30}$ International Panel on Fissile Material, Global Fissile Material Report 2015, (online), $<$ http://fissilematerials.org/library/gfmr15.pdf $>$ 2015.[2].

${ }^{31}$ Analytical Index Article XXI GATT.[602].

${ }^{32}$ ibid.

${ }^{33}$ United Nations Economic and Social Council, Verbatim Report - Thirty sixth meeting of commission "A" (E/PC/T/A/PV/36), Second Session of the Preparatory Committee of the United Nations Conference on Trade and Employment, 12 Agustus 1947.[36].
} 
(iii) taken in time of war or emergency in international relations

Menurut ayat ini, negara dapat menyimpangi ketentuan GATT 1994 ketika terjadi salah satu dari dua situasi yaitu ketika perang atau ketika terjadi kegentingan dalam hubungan internasional. Perang menurut Oppenheim adalah pertikaian antara dua atau lebih negara dengan tujuan untuk mengalahkan satu sama lain dan pemenang akan memaksakan kondisi damai sesuai dengan yang diinginkannya. ${ }^{34}$ Sedangkan menurut Black's Law Dictionary, perang memiliki arti sebagai sebuah konflik angkatan bersenjata antar negara atau pemimpin atau pun antar pihak yang berada dalam negara yang sama. ${ }^{35}$ Selanjutnya berdasarkan putusan WTO pada kasus Rusia dan Ukraina, secara objektif emergency in international relations merujuk pada situasi konflik bersenjata, meningkatnya ketengangan atau krisis, atau ketidakstabilan umum yang melanda suatu negara. ${ }^{36}$ Tidak hanya itu, namun situasi-situasi tersebut juga harus mempengaruhi kepentingan nasional negara terkait: kepentingan pertahanan atau militer. ${ }^{37}$

\section{Sejarah Hubungan antara Jepang dan Korea serta Dampaknya terhadap Perdagangan Bilateral Jepang dan Korea Selatan}

Secara umum, Jepang dan Korea Selatan memiliki perseturuan. Kondisi hubungan yang demikian bukan merupakan situasi yang baru saja muncul, namun telah berlangsung setidaknya sejak lebih dari satu abad yang lalu. Ketegangan diantara keduanya setidaknya dimulai sebab pada tahun 1910 Kekaisaran Jepang mengkolonisasi Korea hingga tahun 1945. ${ }^{38}$ Pada masa pendudukan Kekaisaran Jepang di Korea, terdapat banyak penindasan yang dilakukan oleh Jepang kepada

${ }^{34}$ L. Oppenheim, International Law, Edisi ke-7, Longmans, Green \& Co., London, 1952 dikutip dari Yoram Dinstein, War, Aggresion, and-Self Defence, Edisi ke-4, (Cambridge University Press 2005).[5].

${ }^{35}$ Bryan A. Garner (ed), Black Law Dictionary, (Edisi 10, Thomson Reuters 2009).[1816].

${ }^{36} \mathrm{WT} / \mathrm{DS} 512 / \mathrm{R}$, paras. 7.62-7.77.

${ }^{37} \mathrm{ibid}$, para. 7.76 .

${ }^{38}$ Erin Blakemore, 'How Japan Took Control of Korea', (History, 2018) <https:/www.history.com/news/japan-colonization-korea> accessed 23 November 2019. 
penduduk Korea. Jepang mengambilalih tenaga kerja dan wilayah Korea. Pada masa itu sekitar 725.000 warga Korea dipaksa untuk bekerja bagi Jepang. ${ }^{39}$ Selain itu ratusan ribu wanita Korea juga dijadikan wanita penghibur bagi tentara Jepang. ${ }^{40}$

Setelah masa kependudukan Jepang di Korea berakhir, Jepang dan Korea Selatan berusaha untuk memperbaiki hubungan diplomatik diantara keduanya. Pada tahun 1965, muncul sebuah perjanjian bilateral yang ditandatangani oleh Jepang dan Korea Selatan untuk menormalisasi hubungan keduanya, bernama Treaty on Basic Relations between Japan and The Republic of Korea. Bersamaan dengan perjanjian tersebut, terdapat perjanjian lain yang juga disepakati oleh Jepang dan Korea Selatan yaitu Agreement on the Settlement of Problems Concerning Property and Claims and on Economic Co-operation. Berdasarkan perjanjian tersebut, Jepang wajib memberikan produk dan jasa senilai $\$ 300,000,000$ dan menyediakan pinjaman sebesar $\$ 200,000,000$ apabila diminta oleh Korea Selatan. ${ }^{41}$ Sebagai gantinya Korea Selatan pun melepaskan haknya untuk meminta reparasi dan kompensasi bagi warga negaranya. ${ }^{42}$ Kompensasi bagi para tentara Korea yang dipekerjakan oleh Jepang pun diberikan sendiri oleh Pemerintah Korea Selatan kepada yang masih hidup ataupun kepada keluarganya. ${ }^{43}$

Sekalipun telah terdapat perjanjian untuk memperbaiki hubungan antara Jepang dan Korea Selatan, eksploitasi manusia yang dilakukan Jepang pada masa kependudukannya di Korea beberapa dekade yang lalu membawa dampak pada hubungan perdagangan antara Jepang dan Korea Selatan pada masa kini. Pada tahun 2018, Mahkamah Agung dari Korea Selatan mengeluarkan sebuah putusan yang dianggap tidak selaras dengan perjanjian bilateral 1965 tersebut. Menurut putusan Mahkamah Agung Korea Selatan, dua perusahaan Jepang yaitu Nippon Steel dan Sumitomo Metal Corp., diwajibkan memberikan sejumlah uang kepada

\footnotetext{
${ }^{39}$ ibid.

${ }^{40}$ ibid.

${ }^{41}$ Article I Agreement on the Settlement of Problems Concerning Property and Claims and on Economic Co-operation.

${ }^{42}$ Miki Y. Ishikada, Toward Peace: war responsibility, postwar compensation, and peace movements and education in Japan, (iUniverse 2005).[21].

${ }^{43}$ ibid.
} 
empat warga Korea Selatan yang pernah kerja paksa dan tidak diberikan upah. ${ }^{44}$ Putusan tersebut dikeluarkan sebab Mahkamah Agung melihat bahwa kerja paksa tidak termasuk dalam ruang lingkup hak kompensasi yang dilepaskan oleh Korea Selatan dalam perjanjian bilateral tahun $1965 .{ }^{45}$ Namun Jepang menganggap bahwa hal ini merupakan bentuk pelanggaran dari hukum internasional. ${ }^{46}$

Seperti yang telah dijelaskan pada bulan Juli 2019 Jepang kemudian memberlakukan lisensi ekspor terhadap tiga bahan kimia yang akan diekspor ke Korea Selatan, yaitu: fluorinated polyimide, resists polymer dan hydrogen fluoride. ${ }^{47}$ Penerapan lisensi ekspor terhadap tiga bahan kimia tersebut oleh Korea Selatan dianggap sebagai tindakan yang menyimpang dari Pasal I GATT 1994. ${ }^{48}$ Hal tersebut dikarenakan Jepang tidak menerapkan kebijakan yang sama terhadap 'like products' yang hendak dikirim ke negara anggota WTO lainnya. ${ }^{49}$ Lisensi ekspor tersebut dapat menghabiskan waktu selama 90 hari yang dapat menghambat produksi semikonduktor Korea Selatan. ${ }^{50}$ Tindakan yang juga diambil oleh Jepang selanjutnya adalah menghapus Korea Selatan dari 'white list'perdagangan Jepang. ${ }^{51}$ Tindakan ini juga diikuti oleh Pemerintah Korea Selatan yang juga menghapus Jepang dari daftarnya terkait mitra dagang yang tepercaya. ${ }^{52}$ Oleh Korea Selatan, Jepang dimasukkan ke dalam daftar lain yang dimiliki Korea Selatan yaitu daftar

${ }^{44}$ Wooyoung Lee, 'Japan to bring South Korean court ruling on forced labor to intenational court', (United Press International 2018) <https://www.upi.com/Top_News/WorldNews/2018/11/06/Japan-to-bring-South-Korean-court-ruling-on-forced-labor-to-internationalcourt/7631541482073/?ur3=1> accessed 24 November 2019.

${ }^{45}$ Ock Hyun-Ju, 'Court orders Japan firms to compensate wartime forced labors', (The Korea Herald 2019) <http://www.koreaherald.com/view.php? ud=20181030000606> accessed 24 November 2019.

${ }^{46}$ Youkyung Lee, [et.,al.], 'Why Japan and South Korea Has Their Own Trade War', (Washington Post, 2019) <https://www.washingtonpost.com/business/why-japan-and-south-koreahave-their-own-trade-war/2019/11/25/106fe348-0f54-11ea-924c-b34d09bbc948_story.html> accessed 27 November 2019.

47 WT/DS590/1.

${ }^{48}$ ibid.

${ }^{49}$ ibid.

${ }^{50}$ Celeste L. Arrington, Loc. Cit.

${ }^{51}$ White list Jepang adalah daftar negara-negara yang merupakan tujuan ekspor yang terpercaya. Terhadap negara-negara dalam white list tersebut tidak dilakukan cek perdagangan yang terlalu ketat. Youkyung Lee dan Sohee Kim, Loc.Cit.

${ }^{52}$ ibid. 
negara yang tidak mematuhi ketentuan internasional terkait kontrol ekspor. ${ }^{53}$

Terkait dengan restriksi ekspor yang diberlakukan oleh Jepang, Sekretaris Kabinet Jepang mengatakan bahwa hal tersebut terpaksa dilakukan atas dasar national security sebab Korea Selatan tidak mampu untuk memberikan solusi yang memuaskan terkait dengan isu yang berhubungan dengan permasalahan kerja paksa yang telah dijelaskan di atas. ${ }^{54}$ Selain itu Jepang juga mengatakan bahwa restriksi ekspor terhadap tiga bahan kimia tersebut diberlakukan sebab beberapa perusahaan Korea Selatan telah mengelola bahan-bahan kimia yang dapat digunakan untuk kepentingan militer secara tidak tepat. ${ }^{55}$ Bahkan dikabarkan bahwa ditemukan salah satu bahan kimia (hydrogen fluoride) yang dikirimkan oleh Jepang tersebut kepada Korea Selatan, selanjutnya disalurkan ke Korea Utara oleh pihak Korea Selatan. ${ }^{56}$ Seperti hubungannya dengan Korea Selatan, Jepang juga memiliki hubungan yang kurang baik dengan Korea Utara. ${ }^{57}$

\section{Penerapan Restriksi Perdagangan yang Dilakukan oleh Jepang Terhadap Korea Selatan Berlandaskan Pasal XXI GATT 1994}

Untuk melakukan analisis mengenai kesesuaian tindakan Jepang dengan GATT 1994, perlu diketahui secara spesifik bagian mana dari Pasal XXI GATT 1994 yang sesuai dengan keadaan yang ada. Hal tersebut dikarenakan Jepang tidak menyebutkan secara spesifik huruf apa dari Pasal XXI GATT 1994 yang menjadi landasannya

${ }^{53}$ David Ho, Loc. Cit.

${ }^{54}$ Park Chan-Kyong,[et.,al.], 'Japan-South Korea 'trade war': has Tokyo shot itself in foot?', (South China Morning Post 2019) <https://www.scmp.com/week-asia/geopolitics/article/3016980/ japan-south-korea-trade-war-has-tokyo-shot-itself-foot> accessed 27 November 2019.

${ }^{55}$ Ben Dooley, 'Japan Cites 'National Security' in Free Trade Crackdown. Sound Familiar?’ (New York Times, 2019) <https://www.nytimes.com/2019/07/15/business/japan-south-korea-trade-war-semiconductors. $h$ tml $>$ accessed 25 November 2019.

${ }^{56}$ Grace Shao, 'South Korea-Japan trade tight risks "further escalation" (CNBC Indonesia 2019) < https://www.cnbc.com/2019/07/17/south-korea-japan-trade-war-risks-escalation-impacton-tech-firms.html $>$ accessed 25 November 2019.

${ }^{57}$ Jepang dan Korea Utara memiliki hubungan bilateral yang minim dan relatif tegang. Hal tersebut dikarenakan program pengembangan serta percobaan rudal dan nuklir yang terus dilakukan oleh Korea Utara yang oleh Jepang dianggap dapat berpotensi mengancam 'security' Jepang. Selain itu pada tahun 1970an hingga 1980an, Korea Utara pernah menculik warga negara Jepang yang hingga sekarang menyebabkan Jepang menilai Korea Utara sebagai ancaman terhadap national security Jepang lebih dari sewajarnya. 
untuk menyimpangi ketentuan GATT 1994. ${ }^{58}$ Hal pertama yang perlu dilakukan adalah menentukan huruf mana dari Pasal XXI GATT 1994 yang lebih sesuai dengan pernyataan Jepang. Jepang menyatakan bahwa restriksi ekspor yang dilakukannya terhadap Korea Selatan dilandasi oleh alasan national security. ${ }^{59}$ Dengan demikian huruf (c) Pasal XXI GATT 1994 bukanlah landasan hukum yang dimaksud oleh Jepang sebab national security diatur pada huruf (a) dan (b) Pasal XXI GATT 1994.

Selanjutnya, huruf (a) Pasal XXI GATT 1994 mencegah sebuah negara untuk memberikan informasi yang dianggap bertentangan dengan 'essential security interest'-nya. Sedangkan huruf (b) Pasal XXI GATT 1994 mencegah sebuah negara untuk melakukan tindakan apapun yang dianggap penting untuk melindungi 'essential security interest'-nya. Dalam sengketa antara Jepang dan Korea Selatan ini, hal yang dilakukan oleh Jepang adalah menerapkan lisensi ekspor terhadap tiga bahan kimia. ${ }^{60}$ Di sini Jepang melakukan sebuah tindakan yang mendiskriminasi Korea Selatan, yang menurut Jepang penting untuk melindungi national securitynya. ${ }^{61}$ Dengan demikian huruf yang sesuai dengan pernyataan Jepang adalah huruf (b) Pasal XXI GATT 1994.

Pasal XXI(b) GATT 1994 sendiri memiliki tiga subparagraf. Kriteria dari salah satu dari tiga subparagraf tersebut harus terpenuhi apabila Jepang ingin

${ }^{58}$ Tujuan dari WTO Agreement adalah untuk mewujudkan liberalisasi perdagangan. WTO Agreement menjamin adanya timbal balik antar negara anggota dalam menurunkan tariff dan hambatan lainnya. Namun WTO memberikan fleksibilitas berupa exceptional clause bagi negara anggota untuk dapat menyimpangi ketentuan WTO guna melindungi kepentingan-kepentingan tertentu dari negara yang tidak berhubungan dengan perdagangan. Salah satunya adala national security exception. Klausula pengecualian tersebut dibuat mengingat kedaulatan sebuah negara merupakan hal yang penting untuk dilindungi. National security exception tersebut terdapat pada beberapa perjanjian dalam WTO yang salah satunya adalah GATT. WTO pun telah mengatur ketentuan-ketentuan penggunaan dari exceptional clause agar tidak ada negara anggota yang menyalahgunakannya sebagai hambatan tersembunyi. Sehingga apabila sebuah negara hendak menyimpangi obligasinya dalam GATT, harus berdasarkan pada ketentuan exceptional clause yang ada pada GATT. Penting untuk diketahui Pasal mana dari GATT yang dimaksud oleh Jepang terkait national security.

Lihat: WT/DS512/R, para. 7.79; EC - Computer Equipment, para. 82; WTO, 'Principles of the Trading System' (World Trade Organization) <https://www.wto.org/english/thewto_e/whatis_e/ tif_e/fact2_e.htm> accessed 9 Desember 2019;

${ }^{59}$ Celeste L. Arrington, Loc. Cit.

${ }^{60}$ Ben Dooley, Loc. Cit.

${ }^{61}$ Celeste L. Arrington, Loc. Cit. 
menggunakan Pasal XX(b) GATT 1994 sebagai alasan restriksi ekspor yang dilakukannya terhadap Korea Selatan. Penilaian terkait terpenuhinya salah satu subparagraf tersebut merujuk pada putusan Panel untuk DS512: Russia-Measures Concerning Traffic in Transit. Hal yang dilakukan oleh panel adalah melakukan penilaian secara objektif terhadap subparagraf yang digunakan sebagai alasan oleh Rusia, yaitu subparagraf (iii) Pasal XXI(b) GATT 1994. Selanjutnya panel melihat apakah keadaan, peristiwa atau fakta yang ada telah sesuai dengan subparagraf (iii) Pasal XXI(b) GATT 1994. Dengan demikian untuk menentukan secara lebih detil alasan national security dalam GATT 1994 mana yang dimaksud oleh Jepang, tahap selanjutnya adalah melakukan analisis antara fakta yang ada dengan ketiga subparagraph Pasal XXI(b) GATT 1994. Penjelasan objektif dari subparagraf (i), (ii), dan (iii) Pasal XXI(b) GATT telah dijabarkan di atas. Dari tiga subparagraf tersebut, yang paling tepat untuk digunakan dalam sengketa antara Jepang dan Korea Selatan adalah subparagraf (ii) Pasal XXI(b) GATT 1994. Hal tersebut dikarenakan fakta-fakta yang ada tidak memenuhi secara objektif subparagraf (i) atau (iii) Pasal XXI(b) GATT 1994. Jepang tidak menerapkan restriksi ekspor karena adanya keterlibatan bahan fisi seperti plutonium ataupun uranium. Hal tersebut menyebabkan subparagraf(i) bukanlah alasan national security yang dimaksud oleh Jepang. Selanjutnya pada saat ini, Jepang dan Korea Selatan tidak berada dalam situasi perang atau konflik bersenjata antara satu sama lain. Selanjutnya berdasarkan sejarah dan persitiwa yang baru-baru saja terjadi antara Jepang dan Korea Selatan, jelas terlihat bahwa terdapat ketegangan hubungan diantara keduanya. Namun ketegangan tersebut lebih bersifat politis ataupun ekonomis antara Pemerintah Jepang dan Pemerintah Korea Selatan. Meningkatnya ketegangan dalam hubungan memang termasuk dalam salah satu kriteria dikatakan terjadinya emergency in international relations. ${ }^{62}$ Namun ketengangan dalam artian politik atau ekonomi bukanlah yang dimaksud dalam Pasal XXI(b)(iii) GATT 1994. ${ }^{63}$ Dengan demikian dapat dilihat bahwa fakta yang ada tidak sesuai dengan subparagraph (iii) Pasal

\footnotetext{
${ }^{62} \mathrm{WT} / \mathrm{DS} 512 / \mathrm{R}$, paras. 7.62-7.77.

${ }^{63} \mathrm{ibid}$, para. 7.75 .
} 
XXI(b)(iii) GATT 1994.

Dari pernyataan-pernyataan Jepang yang telah dijabarkan pada sub bab 3.1., dapat dilihat bahwa national security yang dimaksud lebih berhubungan dengan subparagraf (ii) dari Pasal XXI(b) GATT 1994. Hal ini dikarenakan Jepang mengatakan bahwa terdapat bahan kimia (hydrogen fluoride) ${ }^{64}$ yang berasal dari Jepang, kemudian dikirimkan oleh Korea Selatan kepada Korea Utara ${ }^{65}$ Selain itu Jepang mengkhawatirkan bahwa Korea Selatan tidak memiliki pengaturan yang baik terkait tiga bahan kimia yang diberlakukan restriksi ekspor. ${ }^{66}$ Terlebih lagi mengingat bahwa bahan-bahan tersebut dapat digunakan untuk membentuk senjata pemusnah massal. ${ }^{67}$ Merujuk pada penjelasan terkait subparagraph (ii) Pasal XXI(b) GATT 1994 pada sub bab 2.4., dijelaskan bahwa bahan mentah atau lainnya yang jelas diperdagangkan untuk kepentingan militer, termasuk dalam ketentuan Pasal XXI(b)(ii) GATT 1994. Dengan demikian dapat disimpulkan bahwa ketentuan dalam GATT terkait national security yang dimaksud oleh Jepang adalah Pasal XXI(b)(ii) GATT.

Analisis terhadap tindakan Jepang akan dilakukan menurut analisis yang dilakukan oleh Panel WTO terhadap kasus Russia-Measures Concerning Traffic in Transit. Untuk menganalisis tindakan yang dilakukan oleh Jepang terhadap Korea Selatan, peristiwa serta fakta yang ada perlu dianalisis kesesuaiannya dengan Pasal XXI(b)(ii) GATT 1994. Dari analisis yang dilakukan didapati bahwa tindakan suatu negara yang menyimpang dari ketentuan GATT 1994 dapat dibenarkan oleh Pasal XXI(b) GATT 1994 ketika terbukti bahwa 'essential security interest' negara terancam. ${ }^{68}$ Seperti yang juga telah dijelaskan, 'essential

\footnotetext{
${ }^{64}$ Hydrogen fluoride merupakan bahan kimia yang berbahaya. Dalam bentuk gas bahan ini dapat merusak kornea dan menyebabkan kebutaan. Bila terhirup dapat mengakibatkan pembengkakan, terakumulasinya cairan dan rusaknya paru-paru. Bahan ini juga dapat menyebabkan kulit terbakar. Lihat <https://www.wate.com/news/local-news/6-things-to-know-about-hydrogenfluoride/> accessed 6 Desember 2019.

${ }^{65}$ Catherin Kim, Loc. Cit.

${ }^{66}$ Victoria Kim,[et.,al.], 'Japan uses trade restriction as a weapon against South Korea' (LA Times, 2019) <https://www.latimes.com/world-nation/story/2019-07-21/japan-trade-restrictionshit-south-korea $>$ accessed 6 Desember 2019.

${ }^{67}$ ibid.

${ }^{68}$ SR.19/12.[11].
} 
security interest' yang dimaksud adalah national security interest yang berkaitan dengan fungsi klasik dari negara. ${ }^{69}$ Selanjutnya, national security interest tersebut harus secara fakta terbukti terancam sesuai dengan yang tertulis pada subparagraf Pasal XXI(b)(ii) GATT 1994.

National security interest yang dimaksud secara internal adalah pemeliharaan hukum internal dan ketertiban umum, dan secara eksternal terkait perlindungan dari ancaman terhadap wilayah dan penduduk. ${ }^{70}$ Dari penjelasan-penjelasan sebelumnya, dapat dianalisis bahwa penerapan restriksi ekspor yang dilakukan oleh Jepang sebenarnya bertujuan untuk melindungi kepentingan fisik yaitu wilayahnya dan penduduknya. Selanjutnya, harus dilihat apakah kepentingan tersebut terancam oleh fakta yang ada. Barang-barang yang diterapkan restriksi ekspor oleh Jepang kepada Korea Selatan memang adalah barang-barang yang dapat digunakan untuk kepentingan militer. Namun pernyataan-pernyataan Jepang sejauh ini hanyalah sebuah pernyataan. Jepang tidak pernah memberikan bukti bahwa Korea Selatan memperdagangkan atau menyalurkan bahan-bahan kimia tersebut untuk kepentingan militer Korea Utara atau negara manapun. Tidak terdapat bukti nyata atau pun berita yang mendukung bahwa apa yang dinyatakan oleh Jepang itu benar. Namun restriksi ekspor yang tidak berdasarkan bukti tersebut dapat mengakibatkan penurunan keuntungan bagi Korea Selatan.

Jepang merupakan negara produsen terbesar dari hydrogen fluoride dan fluorinated polymide. Dua bahan ini merupakan dua dari tiga bahan kimia yang dikenakan restriksi ekspor oleh Jepang ke Korea Selatan. ${ }^{71}$ Bahan-bahan kimia yang dikenakan lisensi ekspor merupakan bahan-bahan pembuat semikonduktor, yang merupakan bagian yang penting dalam membuat komponen-komponen dalam alat elektronik. ${ }^{72}$ Sebagai negara yang memiliki beberapa perusahaan

\footnotetext{
${ }^{69} \mathrm{WT} / \mathrm{DS} 512 / \mathrm{R} /$ Add.1, Annex C-1, paras. 47, 49-50.

${ }^{70} \mathrm{WT} / \mathrm{DS} 512 / \mathrm{R}$, para. 7.130.

${ }^{71}$ Yen Nee Lee, 'The Japan South Korea dispute could push up the price of your next smart phone', (CNBC Indonesia 2019) < https://www.cnbc.com/2019/07/23/japan-south-korea-disputeimpact-on-semiconductor-supply-chain-prices.html> accessed 9 Desember 2019.

${ }^{72}$ Robert Farley, Loc. Cit.
} 
besar yang bergerak sebagai produsen semikonduktor (SK Hynix dan Samsung Electronics), perusahaan-perusahaan Korea Selatan tentunya mengalami dampak dari kebijakan yang diberlakukan Jepang. ${ }^{73}$ Apabila restriksi ini terus diterapkan, Korea Selatan terpaksa harus mengurangi produksi atau membayar harga yang lebih tinggi untuk mendapatkan bahan yang dibutuhkan. ${ }^{74}$ Dari hal tersebut dapat dilihat bahwa restriksi ekspor yang diberlakukan oleh Jepang dengan alasan national security tanpa bukti yang jelas dapat mengakibatkan penurunan keuntungan bagi Korea Selatan.

Di samping fakta bahwa Jepang tidak memberikan bukti atas argumennya, CISTEC $^{75}$ juga mencatat bahwa terdapat setidaknya 30 kejadian ekspor illegal yang dilakukan oleh Jepang sendiri ke Korea Utara dari tahun 1996 hingga $2013 .^{76}$ Pada tahun 1996, didapati sebuah perusahaan Jepang melakukan ekspor illegal ke Korea Utara. ${ }^{77}$ Barang-barang yang diekspor adalah 50 kilogram sodium fluoride dan 50 kilogram hydrogen fluoride. ${ }^{78}$ Dengan tidak terbuktinya Korea Selatan melakukan ekspor bahan-bahan kimia ke Korea Utara seperti yang dikatakan oleh Jepang, maka pada sengketa Korea Selatan dan Jepang subparagraf (ii) dari Pasal XXI(b) GATT 1994 tidak terbukti. Dengan penelitian yang dilakukan, ditemukan bahwa national security interest atau yang disebut sebagai essential security interes Jepang tidak terancam menurut ketentuan GATT 1994. ${ }^{79}$ Dengan demikian tindakan yang dilakukan oleh Jepang terhadap Korea Selatan tidak sesuai dengan ketentuan dalam GATT 1994.

${ }^{73}$ The Japan Times, 'Economist warns on larger ripple effect of Japan-South Korea trade war', (The Japan Times, 2019) <https:/www.japantimes.co.jp/news/2019/09/28/business/economist-warnslarger-ripple-effect-japan-south-korea-trade-war/\#.Xe4Gn25FzD4> accessed 9 Desember 2019.

${ }^{74}$ ibid.

${ }^{75}$ CISTEC adalah singkatan dari Center for Information on Security Trade Control. CISTEC merupakan organisasi yang berbasis di Tokyo yang melakukan riset dan analisis terhadap isu-isu perdamaian dan keamanan yang berkaitan dengan pengaturan ekspor. Lihat: <https://www.cistec. or.jp/english/about/index.html> accessed 15 Februari 2020.

${ }^{76}$ Jang Na-Rye, 'Report find illegal exports to N. Korea came directly from Japan, not S. Korea', $<$ www.hani.co.kr/arti/english_edition/e_international/901605.html $>$ accessed 6 Desember 2019.

77 ibid.

${ }^{78}$ ibid.

${ }^{79} \mathrm{WT} / \mathrm{DS} 512 / \mathrm{R}$, paras. 7.79 dan 7.82 . 


\section{Kesimpulan}

Salah satu perjanjian dalam perdagangan internasional di bawah WTO yaitu General Agreement on Tariff and Trade 1994 memiliki national security exception. National security exception diatur dalam Pasal XXI GATT 1994 yang memiliki judul security exceptions. Pasal tersebut memiliki tiga huruf; (a) dan (b) untuk national security serta (c) untuk international security. Huruf (a) berfungsi untuk mencegah negara memberikan informasi yang bertentangan dengan essential security interestnya dan huruf (b) berfungsi untuk mencegah negara melakukan tindakan yang dianggap penting untuk melindungi essential security interest-nya atau yang dapat disebut juga sebagai national security interest. Menurut Analytical Index Article XXI GATT, negara memiliki diskresi dalam menentukan apa yang dimaksud dengan essential security interest. Namun, national security yang dimaksud dalam GATT 1994 adalah terkait fungsi klasik negara yaitu memelihara hukum internal dan ketertiban umum negara tersebut serta melindungi kepengtingan fisik wilayah dan penduduknya. Selain itu didapati bahwa untuk menggunakan alasan pengecualian dalam Pasal XXI(b) GATT 1994, salah satu dari subparagraf pasal tersebut harus secara objektif terbukti.

Jepang menerapkan restriksi ekspor terhadap Korea Selatan dengan alasan untuk melindungi national security-nya karena Korea Selatan mengirim bahan-bahan kimia kepada Korea Utara untuk kepentingan militer. Namun, tidak terdapat bukti konkrit bahwa Korea Selatan melakukan apa yang dituduhkan oleh Jepang. Sehingga Jepang tidak dapat mendasarkan tindakannya menurut Pasal XXI(b) GATT 1994 sebab tidak satupun dari subparagraph pasal tersebut secara objektif terbukti.

\section{Daftar Bacaan}

\section{Buku}

Shawkat Alam, [et.,al.], (eds), International Trade Law and The WTO (The Federation Press 2013).

Peter van den Bossche, [et., al.], Pengantar Hukum WTO (World Trade Organization) (Yayasan Obor Indonesia 2010). 
Yoram Dinstein, War, Aggresion, and-Self Defence (Cambridge University Press 2005).

Bryan A. Garner (ed), Black Law Dictionary (Edisi 10, Thomson Reuters 2009

Miki Y. Ishikada, Toward Peace: war responsibility, postwar compensation, and peace movements and education in Japan (iUniverse 2005).

Prabhakaran Paleri, National Security: Imperatives and Challenges (Tata McGrawHill 2008).

\section{Dokumen Hukum Internasional}

Agreement on the Settlement of Problems Concerning Property and Claims and on Economic Co-operation, 1966.

General Agreement on Tariffs and Trade, Minutes of Meeting (C/M/159), 1982.

General Agreement on Tariffs and Trade, Summary Record of the Twelfth Session (SR.19/12), 1961.

General Agreement of Tariff and Trade (GATT, 1994).

Japan - Measures Related to the Exportation of Products and Technology to Korea (WT/DS590/1), 2019.

Panel Report, United States - Trade Measures Affecting Nicaragua (L/6053).

Russia - Measures Concerning Traffic in Transit (WT/DS512/R), 2019.

UN Economic and Social Council, Second Session of the Preparatory Committee of the United Nations Conference on Trade and Employment: Verbatim Report (E/PC/T/A/PV/36), 1947.

World Trade Organization, WTO Analytical Index GATT-Article XXI.

\section{Laman}

Ben Dooley, [et.,al.], 'Japan Imposes Broad New Trade Restrictions on South Korea' (New York Times, 2019) <www.nytimes.com/2019/08/01/business/ japan-south-korea-trade.html>.

Ben Dooley, 'Japan Cites 'National Security' in Free Trade Crackdown. Sound Familiar?' (New York Times, 2019) <https://www.nytimes.com/2019/07/15/ business/japan-south-korea-trade-war-semiconductors.html>. 
Catherine Kim, 'The Escalating Trade War Between South Korea and Japan, Explained' (Vox, 2019) <www.vox.com/world/2019/8/9/20758025/tradewar-south-korea-japan>.

Celeste L. Arrington, 'Japan claims it's restricting exports to South Korea because of 'national security'. Here is the real reason why' (Washington Post, 2019) $<$ https://www.washingtonpost.com/politics/2019/07/18/japan-claims-itsrestricting-exports-south-korea-because-national-security-heres-real-reasonwhy/>.

Erin Blakemore, 'How Japan Took Control of Korea', (History, 2018) <https:// www.history.com/news/japan-colonization-korea>.

Grace Shao, 'South Korea-Japan trade tight risks "further escalation" (CNBC Indonesia 2019) <https://www.cnbc.com/2019/07/17/south-korea-japantrade-war-risks-escalation-impact-on-tech-firms.html $>$.

Jang Na-Rye, 'Report find illegal exports to N. Korea came directly from Japan, not S. Korea', <www.hani.co.kr/arti/english_edition/e_international/901605. html>.

Ock Hyun-Ju, 'Court orders Japan firms to compensate wartime forced labors', (The Korea Herald 2019) <http://www.koreaherald.com/view. php?ud=20181030000606>.

Park Chan-Kyong,[et.,al.], 'Japan-South Korea 'trade war': has Tokyo shot itself in foot?', (South Cina Morning Post 2019) <https:/www.scmp.com/week-asia/ geopolitics/article/3016980/japan-south-korea-trade-war-has-tokyo-shotitself-foot>.

Robert Farley, 'Japanese Tech Export Controls on South Korea?' (The Diplomat, 2019) <www.thediplomat.com/2019/07/japanese-tech-export-controls-onsouth-korea/>.

Satoshi Sugiyama, 'Japan, 'Surprised' by South Korean Response to Export Control, Accuses Seoul of Trying to Make The Issue About Free Trade' (The Japan Times, 2019) <https://www.japantimes.co.jp/news/2019/07/10/business/ japan-surprised-south-korean-response-export-control-accuses-seoul-tryingmake-issue-free-trade/>.

The Japan Times, 'Economist warns on larger ripple effect of Japan-South Korea trade war', (The Japan Times, 2019) <https://www.japantimes.co.jp/ news/2019/09/28/business/economist-warns-larger-ripple-effect-japansouth-korea-trade-war/\#.Xe4Gn25FzD4>. 
Victoria Kim,[et.,al.], 'Japan uses trade restriction as a weapon against South Korea' (LA Times, 2019) <https:/www.latimes.com/world-nation/story/2019-07-21/ japan-trade-restrictions-hit-south-korea $>$,

Wooyoung Lee, 'Japan to bring South Korean court ruling on forced labor to intenational court', <https://www.upi.com/Top_News/WorldNews/2018/11/06/Japan-to-bring-South-Korean-court-ruling-on-forcedlabor-to-international-court/7631541482073/?ur3=1>, 6 November 2018.

WTO, 'Principles of the Trading System' (World Trade Organization) $<$ https:// www.wto.org/english/thewto_e/whatis_e/tif_e/fact2_e.htm>.

Yen Nee Lee, 'The Japan South Korea dispute could push up the price of your next smart phone', (CNBC Indonesia 2019) <https://www.cnbc.com/2019/07/23/ japan-south-korea-dispute-impact-on-semiconductor-supply-chain-prices. html>.

Youkyung Lee, [et.,al.], 'Why Japan and South Korea Has Their Own Trade War', (Washington Post, 2019) <https://www.washingtonpost.com/business/whyjapan-and-south-korea-have-their-own-trade-war/2019/11/25/106fe3480f54-11ea-924c-b34d09bbc948_story.html>. 
Jesika Althea: Restriksi Perdagangan Internasional...

--halaman ini sengaja dibiarkan kosong-- 